\title{
Andrada Fătu-Tutoveanu
}

\section{Masterpieces in an Inferno. Censorship in Cold War Translation Experiences (Micneln Ghiţescu's and Antonneto Ralion's Memoirs)}

\begin{abstract}
The difficult problem of accurately translating both form and message takes a complicated turn when we refer to the translation of literature under Cold War totalitarian regimes. On the one hand, translation was a field in which many Romanian writers or prestigious intellectuals took refuge when banished from other cultural or academic professions. On the other hand, the system involved all along the phenomenon of censorship and self-censorship, literary purges and the organisation of secret funds. These political interferences that marked the translation process are discussed in the memoirs which serve as the focus of this paper. Keywords: Romanian Communism; Censorship; Cold War; Memoirs; Micaela Ghițescu; Antoaneta Ralian.
\end{abstract}

\section{ANDRADA FĂTU-TUTOVEANU \\ Babeș-Bolyai University, Cluj-Napoca, Romania andrada.pintilescu@gmail.com}

DOI: 10.24193/cechinox.2020.39.05

\author{
"The past is a foreign country; \\ they do things differently there" \\ (L. P. Hartley)
}

\section{Introduction. The Brave \\ New Cold War World}

$\mathrm{T}$ raduttore, traditore... The difficult problem to which this pun refers that of translating accurately, while being faithful to both form and message - is further complicated by the specific political aspects of censorship when we refer to the translation of literature under totalitarian regimes. Focusing on Cold War Romania, the field of translation constituted a refuge for many Romanian writers or academics when no longer allowed to publish, teach or perform other cultural or academic professions. The system of censorship and self-censorship was structured in a complicated manner, following the Soviet model, from minor to major cuts, exclusions and "rehabilitations", from clear lines to follow to the rewriting of the texts (as the quotation below reveals), from literary purges 
to the organisation of secret funds, despite some differences marked by the political shifts or change of preferences from a decade to another.

M. Novicov expressed his opinion in favour of revising the censorship filter: 'I think the exigency, sometimes exaggerated, needs revision. ... We've reached a situation in cinematography in which practically, in a great proportion, the scripts are written there [at the Committee for Cinematography.] How can we actually attract the writer when he doesn't have the satisfaction of his work? The writer must be helped to finish the script himself. Since the Committee for Cinematography substitutes him and does this in his stead [the rewriting of the script] [...], this cannot attract the writer [emphasis added $]^{1}$.

These political interferences that marked the translation process are discussed in the memoirs approached in this paper. The authors, Antoaneta Ralian and Micaela Ghiţescu, were renowned translators who worked with world literature masterpieces, the former from English and the latter from Portuguese. Their memoirs describe both the "pleasures and the pains" of translating major literary pieces in a highly restrictive system. They offer an interesting and accurate perspective (that of the insiders of this systems) on the politicised translation process.

Departing from the discussion on the political intrusions in the translation of literature, the current paper also takes into account the characteristics of life-writing (especially women's personal narratives) during the Cold War, as a topic that was addressed in the author's previous research (2015). The paper aims to identify and compare the experiences of the two selected translators and their shared memories regarding both the censoring process and the strategies to elude it or allow masterpieces to be accepted for publication.

The Romanian publishing system as well as all the mechanisms and institutions concerning culture (and literature in particular as a major propaganda tool but also newspapers and magazine, cinema and later television) were de/restructured starting with 1948, following the model of the Soviet Union "cultural front" (see Fitzpatrick 1992).

The 'new man', the 'new times' [...] were described in the langue de bois which appeared even in my intimate pages. The relationships between people, including love - reinforced by the work virtues of the protagonists - had to be 'new', as well as the attitude towards work and art (the means becoming, paradoxically and artificially, traditionalist). The novelty, sometimes unknown, with a certain theoretical magnetism but not verified by practice, was permanently invoked, with all its threatening load towards the 'old' and implicitly towards consecrated philosophical, moral, aesthetic values $^{2}$.

Departing from the idea expressed by the Soviet ideologists, the local political leaders, such as the Romanian General Secretary at the time, showed their involvement in culture and stated that literature was "an area of ideology and actually one 
of the most significant, due the power it possesses to influence" 3 people. The need to exercise absolute control and censorship of such a system required institutions that would centralise, manage and/or supervise all funds, publications and literary activities (translations among them) as well as organise regular meetings, important due to their multiple roles (control, propaganda, purge practices and so on). Thus, I argued elsewhere that similarly to the other satellite countries, Romania was politically and culturally colonised ${ }^{4}$ : "I consider that several features of the colonial phenomenon can be applied to the communist case (the military occupation, the control at all political, social, economic and cultural levels, the paternalist ideological discourse)"5. It meant, among other things, applying the "Stalinist blueprint ... based on a unique strategy of transforming national political cultures into carbon copies of the USSR" ${ }^{6}$ and, thus, adopting a Soviet cultural canon ${ }^{7}$.

Through a massive institutional reorganisation, the Soviet model was transferred onto local literature, visual arts and all areas of culture and education, to mention just the field that is the focus of study. This involved a huge amount of translations from Russian,

strengthened by their local carbon-copy imitations - articles or books copying the ideas and wooden language of the 'metropolitan' centre ... At the cultural level, the massive and well-organised mechanism and infrastructure of implementing (at a large scale) the Soviet 'blueprint' or model justifies the association between this complex process of domination (in its mechanisms of acquiring and generalising control over culture and all other social areas) and a process of specific cultural (informal) colonization ${ }^{8}$.

From science to education, culture and everyday issues, the fact that the metropolis (officially depicted only as a protective, friendly sibling) was in possession of the ultimate truths was beyond questioning. In this context, translations were an essential tool to convey these undisputable knowledge: a special publishing house was created, Cartea Rusă (which published in 1953 alone 1,650 titles in $22,550,000$ copies $)^{9}$, in the field of science as well as social science "an important number of published articles were represented by translations from specialised journals in the Soviet Union"10 and, essentially, "in 1948-1949, 80\% of the school textbooks were translations from the Soviet textbooks" ${ }^{11}$. As previously argued $^{12}$, the process of cultural transfer (associated to what I called a specific type of informal colonisation) of the Soviet cultural paradigm took place disregarding the local differences and unfavourable context, represented by an almost total absence of interest of the local intellectuals both in the Soviet culture and in the leftist ideology (the Romanian 1920s-1940s cultural elite being right-wing oriented). This had made Romanian culture less predisposed to the absorption of the Soviet cultural model, which makes the political and cultural "occupation" even more ostentatious.

All the principles, rules, interdictions [...] that made a coherent system, imported from the Soviet Union and popularised and adapted in Romania by [Leonte] Răutu and a group of activists, were not born all at once, like 
Venus from the sea foam. They were gradually introduced, since 1948 , accomplished $[\ldots]$ their mechanisms and structure, reaching after a few years (1951-1952) the full speed. This paroxysmal moment was however followed by a brutal downfall. Stalin's death (in March 1953) relaxed the war in time of peace communist paradigm - unyielding, blunt, anti-intellectual, paranoid, suffocating ${ }^{13}$.

Institutional reorganisation was a significant strategy, applied at all levels: for instance, at the top level, The Romanian Academy changed its name in June 1948 to the Academy of the Popular Republic of Romania and underwent major changes after the Soviet model. Other radical interventions took place after January 1949, when legislation explicitly focused on measures for the "stimulation of scientific, literary and artistic activities" was issued. An institution that was considered important for the regime, the Writers' Union, was founded in 1949 continuing the Romanian Writers' Society, established in 1908. The new institution functioned at the national level, with local branches, and had an effective role, controlling important resources (from funds to numerous properties) and organising the activities of the writers according to the official requirements.

Writers were expected to write for these mass audiences and... establish a dialogue (sometimes direct, through meetings) and rewrite their works (which were not 'reflecting' the real problems or were sending the wrong ideological message ${ }^{14}$.
Besides these visible institutional changes concerning culture, the authority actually controlling the publications was connected to another (political) structure, which focused on the new priorities, agitation and propaganda. Until the beginning of 1948, these activities were coordinated by the Central Department of Political Education [Secţia Centrală de Educaţie Politică - SCEP] and its local branches and multiple committees ${ }^{15}$. This structure was in charge with the supervision/censorship of publications, also collaborating with the Ministry of Information and secret services (Siguranţa and later Securitatea). It supervised the implementation of the Party's decisions within all significant institutions that dealt with culture. These were numerous, organised hierarchically so as to ensure centralised control and highly bureaucratised: the Ministry of Public Education, the Ministry of Arts and Information (later reorganised into the Committee for Arts, the Ministry of Culture, and the State Committee for Culture and Arts), the Academy of the Romanian People's Republic, the General Directorate for Press and Print, the Writer's Union and the Artists' Union and all the cultural, artistic and press institutions regarding cinema, radio and so on ${ }^{16}$. The institution had also the authority to recruit the staff for all cultural institutions, which was a highly political mission. Antoaneta $\mathrm{Ra}-$ lian spoke about her first job and how she was recruited as "fresh blood" for the system; she made a dark pun between job and $\operatorname{ciob}^{17}$ (piece of broken glass, in Romanian), to suggest the discomfort of working in a field which disfigured culture.

The structure changed its name and organising formula over time (the habit 
was to use the initials, after the Soviet model so the actual names were usually void of meaning. Moreover, the person in charge stayed the same between 1947-1965. This person remained significant for the history of Romanian censorship, Leonte Rău$\mathrm{tu}^{18}$. He was the head of this department, renamed the Directorate of Propaganda and Agitation of CC of RWP and later, in 1950 the Department of Propaganda and Agitation (SPA). Concerning this faithful implementation, Răutu himself declared before his death in the early 1990s that "Communist Romania was entirely built following the Soviet model"19. The different "institutional channels" ${ }^{20}$ contributed - as well as the press, literary circles or the recently founded school of literature - to achieving and legitimising the major literary shift ${ }^{21}$.

\section{Life Writing: Sharing the "Pleasures and Pains" of Translating during Communism}

"We would be nothing without our memory"

(Annie Bentoiu)

"Writing is a process, a journey into memory and the soul"

(Isabel Allende)

fter the fall of the Communist "dom-
nino", the Romanian audience and,
naturally, the publishing system showed
an immense interest in life writing. The
fascination for personal narratives - either
retrospective accounts of the Cold War or
accounts already written but censured or
self-censured, or a hybrid between the two -
can be explained, I believe, in the light of this collective post-traumatic quest for the lost time and for reconstructing the experiences kept in secrecy. Life writing is most likely the best suited genre for such a journey of individual and collective self-discovery, as in this type of introspection "the mechanisms of existence are decomposed consistently and methodically and later recomposed so as to create and re-create a world"22.

From the perspective of gender studies and particularly in the feminist approach, personal narratives gain in relevance. Also, the quality and depth of most of these introspections -in terms of both personal and historical experiences - go beyond the relevance of the personal narrative for gender issues and gendered experiences. Therefore, personal narratives, seen as reflection of female experiences and interpretations of events, represent a key object of analysis for gender studies. I consider this connection between gender and the genre extremely relevant mainly because these narratives are not and cannot be, critics consider, neutral from a gender perspective. Thus, while reflecting individual as well as collective experiences and traumas during the dictatorship, these writings - belonging to women connected to the profession of writer or translator, educated and/or performing in the midst of the cultural elite - cannot leave aside the gendered perspective. Moreover, personal narratives can provide the researcher with a double perspective, revealing the woman's social experience and her introspections.

The focus here is on two female translators, both shy to publish fiction or personal narratives until very late in life due to the proximity of masterpieces, which convinced both that they needed more talent and more to say. However, both 
acknowledged the fact that the translation was an act of "re-creation" 23 , in which a translator invested part of herself and her experience and biography. Attracted on the path of life-writing by some interviewers, both decided eventually to write their stories, which were turned into Herstory. Their biographies are different and yet equally influenced by the political context and History. The comparison between them is justified first of all by the profession they shared and by the fact that they belonged practically to the same generation (Ralian was born in 1924 and Ghiţescu in 1931), experiencing the same period and working in the same translation system. Moreover, as they wrote their memoirs almost simultaneously (and published in 2012 and, respectively, 2014, with additional texts in periodicals, in Ralian's case these were also gathered in a volume after her death ${ }^{24}$ ) and gave memorable interviews (to Eugenia Vodă, among others), the reader has the possibility to compare experiences and add complementary pieces to the historical puzzle and to the gender approach.

Micaela Ghiţescu's experience, shared in her memoirs, is that of her tragic youth as a political prisoner. In an interview taken by Eugenia Vodă they agreed Ghiţescu was, above all things, "a professional survivor." ${ }^{25}$ Born and raised into an educated family, the daughter of an appreciated doctor and a mother related to some wellknown intellectuals (the Papacostea family), Ghiţescu mentions a focus on foreign languages in her education, something for which she also showed talent, as did Antoaneta Ralian.

We, the children, almost before actually knowing how to speak, learned
German, almost as a native language. Believing that it is the most difficult language for the Romanians to learn, my father insisted on our learning it from early childhood. In my home, French was spoken currently and it was transmitted to us, the children, together with German, almost as a native language... Classical and contemporary French literature and even the latest novels published in Paris, as well as the Revue des Deux Mondes, were in our home library. My mother had subscriptions for Marie Claire and Modes E Travaux, my father ordered his medical books, as well as children's books, from Paris ${ }^{26}$.

Ghiţescu's destiny would later be, for better and for worse, related to this interest in foreign languages. As a teenager she decided to enrol at the French Institute in Bucharest but the major shifts in Romanian (and world politics) led her to a tragic denouement. After the fall of the Iron Curtain, the teachers and students of the French Institute in Bucharest kept correspondence with their former professor, Marcel Fontaine, now in France. Those involved in this correspondence, as well as "other people that had gravitated around the French Institute, around 100 people), were arrested, tried and sentenced to punishments from 2 years to life sentence" 27 for the crime of "espionage in favour of a foreign country" ${ }^{28}$. Her references to prison life and trauma are, indeed, those of a survivor. She writes without bitterness, despite having survived political prisons. She also became a successful professional, rebuilding her life against all odds: the political and social stigma and great personal 
loss. Initially all jobs associated with languages (including teaching) were denied to her, as they "involved contacts with other countries"29. Ironically or not, foreign languages would later help her earn a living as a translator of Portuguese literature. Following her tragic prison experience related to the French Institute, she started studying Spanish and Portuguese in rather improvised conditions $s^{30}$ and as Portuguese was not studied at the University and there were no diplomatic connections with Portugal at the time, very few people knew the language and culture. This helped her become later the "Portuguese specialist" in the field of translations. In this area, she could exercise a form of cultural survival that served not only herself but also the readers:

For the Romanian reader, the translated foreign literature meant not only an open window towards a world considered normal, but also - as the cinema and television were, with few exceptions, unbearable - an escape, a refuge from the daily cultural aggressions of imposture. When the publication of a translation was announced, queues were formed at the bookstores ${ }^{31}$.

Ghiţescu's memoir focused explicit$1 y$, from the very title, on the ambivalence between "forgetting/oblivion" and "remembering" ${ }^{32}$. About her strategies, she says she followed no path other than the "meanders" of her memory and thought "occasionally hindered by oblivion" ${ }^{33}$. She emphasises the fact that this personal narrative is her only book, as she had "no more time" ${ }^{34}$. Indeed, Micaela Ghițescu died in 2019 and her memoir remains, besides a few interviews, her confession about surviving and resisting Romanian totalitarianism. Therefore, memory served a vital function, it was used as a survival exercise.

It is a field in which a survivor of the political prison was able to find satisfaction in overcoming censorship, sometimes partially, through words or paragraph elusions, at other times more substantially: "The fact of managing to elude it offered great satisfactions. Indeed, we considered it a reward which in our turn we offered to the readers when a subversive book "passed" (eluded censorship $)^{35}$. Besides a form of resistance, it can be considered a form of serving memory, by "saving" books from oblivion (especially from less accessible literatures, such as the Portuguese and Brazilian ones) and by connecting the isolated Romanian cultural to the collective heritage of world literature.

Memory is not only individual but cultural: memory, though we may experience it as private and internal, draws on countless scraps and bits of knowledge and information from the surrounding culture, and is inserted into larger cultural narratives. This is a relationship that goes both ways, of course. If individual memories are constructed within culture, and are part of cultural systems of representation, cultural memories are constituted by the cumulative weight of dispersed and fragmented individual memories, among other things ${ }^{36}$.

The concern for retrieving the past from oblivion stands out both in her memoir and as an editor of a publication called Memoria. About her strategies, she says 
she followed no path other than the "meanders" of her memory and thought "occasionally hindered by oblivion" ${ }^{\prime 37}$ and her work attempts to concentrate in her only book, as she emphasises, the essence of her story which could not be otherwise than connected to History.

The access to the elitist translation system came by chance: "my actual "big bang' came about when a writer, a family friend, suggested that we should translate together for the Univers publishing house (which at that time was called the State Publishing House for World Literature)"38. Despite being given only partial credit for this translation, this brought Ghiţescu a better contract, the translation of Henry Fielding's Joseph Andrews. But her political record would continue to haunt her. By mistake or not, Ghiţescu's name was misspelled in the book and during this episode she later narrated how she was intimidated by her past as a former political prisoner (although amnestied) and threatened with legal and professional consequences ${ }^{39}$. Although the head of the publishing house and her own employer supported her, the system could not be defeated and the ambiguity remained about her name on the first edition. But, by way of compensation, further contracts were offered to the translator and her career flourished.

Ghiţescu described the act of translation as being "an act of creation at the same time. You walk beside the writer you translate. Where he put his foot, you also put yours, and after leaving his trace, you leave yours" ${ }^{40}$. Her career started, as it did for many in the field of translation during the 1950s-1960s, as the alternative left when writing or teaching were excluded from political records as the most influential activities. "Dangerous" class enemies were to be marginalised from influential areas, Ghiţescu herself recounting how she was required to sign a document renouncing all future claims on access to teaching activities. However, she mentioned more than once the satisfactions she experienced as a translator.

The other figure in focus here, Antoaneta Ralian, was perhaps the most reputed and prolific translator during the Cold War. A translator of British and American classics, as well as of contemporaries (i.e. Saul Bellow), Ralian described the censorship system from within, having worked both as a censor and as a translator. She belonged to a "fresh" generation of graduates that were co-opted by the system. She confessed it was a very painful activity to act as a censor and that she later found her true vocation in translations.

\section{Saving Masterpieces from the "Bibliocaust": Censorship Practices}

$\mathrm{T}$ The assimilation of the Soviet model in form and content also had to offer the illusion of enthusiasm. Concerning this simulation of enthusiasm, Paul Cornea an intellectual and "insider" in the system (whose case - or rather certain elements that make it relevant for the discussion of this cultural paradigm shift - will be tackled below) - mentioned in his memoirs an excess of obedience in the servile attitudes of the late 1940-1950s local Communist elite ("fabricated" or imported, we might add, both at the political and cultural level).

First, a series of writers were accused of collaboration [with the enemy], then of ideological errors and pacts 
with the German fascists, which created panic and confusion among writers, who feared massive retaliation and, as a consequence, joined the Communist Party or complied with immediate political orders, writing frantically about translations of Soviet literature. [...] In books stores, publishing houses and libraries the purge of older books was radical. [...] Many private or public libraries were burned, tens of thousands of books were thrown away, transported into dark basements and cellars, some of the most important archives were set on fire ${ }^{41}$.

While in the case of cultural elites the purge meant a series of measures, from the prohibition to publish to their being sentenced to prison, book purges had their own dramatic and violent history - what was called "book holocaust" in Newsweek or "bibliocaust" in Time magazine ${ }^{42}$. Investigating the case study of the purge having taken place at a county library (located in Braşov) and the creation of secret funds, Nazare also discussed the excess of obedience mentioned by Cornea, leading sometimes to absurd situations (forbidding even harmless books and so on). "Becoming a second nature after almost half a century, self-censorship would sometimes exceed censorship itself $f^{43}$.

The shift involved culture at all its levels and areas, the most visible aspects being the new (as well as the restructured, so as to become centralising) cultural institutions and the massive import of Soviet cultural patterns and products, the translation of Soviet books being an essential area, as mentioned above. Also, most visible
- especially in periodicals that recorded closely, both explicitly and implicitly, the ongoing changes - was the shift taking place in language. This "Newspeak" was artificially adopted by (actually imposed upon) the local writers and ideologists that "would assume the imported Soviet vocabulary ... but only declaratively, in order to cope with the authorities, without caring about the actual effect of those words and slogans ${ }^{44}$.

Mircea Eliade's diary covering the early 1940s (when he was a diplomat in Portugal) exhales the fear towards the perspective (later turned into a fact) of the Soviet "takeover". As his diary reveals it, Eliade was conscious that the purge would include him and his works due to his former political views and actions (Victor Cădere, the ambassador and his superior in Portugal, would indeed be arrested after his return to Romania) and that he would not be able to continue his literary and academic work in the new cultural context. Several entries in the diary mention the purge he was indirectly aware of: "this evening the intern news that I listen to on the Romania Radio announced new purges" 45 , adding days later that "among the people guilty for the country's disaster there were 'first range writers'... that have already been arrested" ${ }^{\prime 6}$. Indeed, the purge - focused at first on the writers known to have rightist views - reached paranoid levels.

The names of the authors who had left the country - even legally - were erased from the records of the public libraries, from bibliographies, and could not be quoted. And as the number of these authors was significant and it was difficult for one to keep 
informed on this, the famous Council of Socialist Culture and Education would periodically circulate lists with the outcasts to the public libraries ${ }^{47}$.

Antoaneta Ralian was able to describe the censorship system from within as having worked in the front line of the system. Her testimony is even more valuable because of that. As a young graduate (in the late 1940 s, when a dramatic purge was taking place in the "cultural field", as things were explained to her), as she was could speak several languages, she was employed by the system that was looking for "fresh blood" among the youth ${ }^{48}$.

Besides belonging to a more "harmless" category of young graduates, whom the regime saw as being easier to mould, the account suggests rather than relates straightforwardly (as in all personal narratives, what is left untold is also significant). Perhaps, considering the period, we may read between the lines and find a connection to her being a young Jewish intellectual, a category that provided the system with an alternative to the purged categories. The job was at the Department for Library Purges (Departamentul de Epurare a Bibliotecilor) and it involved precisely the activity of "cleansing" the libraries, through a series of strategies. The focus was on excluding a large range of authors and topics that were considered antisocialist, capitalist or imperialist, religious, mystical, esoteric, erotic, subversive etc. ${ }^{49}$ The translator spoke about this first job as being a source of pain for a literature lover, especially as this was the most radical period. The censorship strategies consisted, she writes, of three categories: "the permanent elimination of the books from the libraries..., their transfer to the ' $\mathrm{S}$ ' fund (meaning Secret, where the majority of the books landed and where only a few chosen individuals had access) and the preservation of harmless books in the libraries" ${ }^{450}$.

I, the same person who became the reputed translator, attended on a regular basis the courses on Philosophy and Aesthetics, George Călinescu's and Tudor Vianu's lectures, and felt uplifted when leaving the class, felt proud as if I were flying on my high heels, I now had to take Kant and Leibniz out of the libraries. I eliminated from the libraries some erotic authors whose books I was to translate fifty years later ${ }^{51}$.

She used the privileges of life-writing to explain that she had few options and that she required a transfer as soon as possible, ending up in the publishing house system. This was considered inferior on the political scale but, after a period of doing bureaucratic work, she became a translator in the 1950s. After 1964, she translated a large range of famous authors (Henry James, Virginia Woolf, Charles Dickens, Saul Bellow, Iris Murdoch and many others). This was also possible due to the changes happening in Romanian politics in the 1960s, which meant an increased distance from the Soviet Union and cultural diversification.

At the beginning of the 1960s, Romanian politics was rebooted, distancing itself from the centralised vision promoted by Moscow. ... From a social point of view, Romania heeded the political changes taking place in the 
early 1960s and the population witnessed a wind of change towards freedom.... A return to normality ${ }^{52}$.

It was the period of the cultural thaw, when the translation field reflected the political changes very well and shifted from the Soviet "colonisation" paradigm of the early 1960s towards national values (Ceauşescu's National Communism). embracing, for a time, openness towards the West. In the field of literature, this involved an opening towards world literature (other than Russian) and different institutional changes.

The beginning of the seventh decade brought a new organisation of the publishing system by the creation of Meridiane Publishing House in 1960, revigorating the activity of $\mathrm{ESPLA}^{53}$ (now renamed Editura pentru Literatura ${ }^{54}$ ), including important translations from Western literature and launching, in 1961, the monthly journal Secolul 20 [The 20th Century], a periodical on world literature topics, edited by the Writers' Union. Still, even now the liberalisation was limited ${ }^{55}$.

In this context, translators such as those approached in this study had both the training and the instinct to contribute to this trend and make a career by translating a diversity of works inaccessible before (some of them world literature masterpieces). This amounted to a return to normality and a connection to the "free world" after suffocating years.

For the Romanian reader, the translated foreign literature meant not only an open window towards a world considered normal, but also, - as the cinema and television were, with few exceptions, unbearable - an escape, a refuge from the daily cultural aggressions of imposture. When the publication of a translation was announced, queues were formed at the bookstores ${ }^{56}$.

Censorship survived, despite the concessions. The mingling became, however, negotiable to a point and accepted nuances and diversification. Both translators describe the adventurous process of getting to translate certain authors and how everything was censored and even self-censored, from the author and the title to the particular choice of words and references. The translators were aware of the "translation canon", as I would call it, a set of rules that made a book, paragraph or sentence pass the censorship test or not.

Before the translation of a book - even where a classic work was concerned and before its appearance in bookstores (or rather 'disappearance', as the majority of the translated books were sold in a clandestine manner, and the number of copies was insufficient even when it meant dozens of thousands) - the translator had to face several difficulties. The most powerful obstacle, and at the same time the most insidious and dangerous, was the censorship. The fact of managing to elude it offered great satisfactions. Indeed, we considered this a reward which, in our turn, we offered to the readers when a subversive book 'passed' 57 .

As these translators attest, every author and every title had their own translation 
story and many strategies were involved in tricking the still vigilant censorship apparatus. Once the author and the book were accepted, the translator had to avoid making "dangerous" insertions (from the title to the word choice) and intrusive changes, such as the "sweetening" of love scenes and, the most costly strategy, the suppression of words, paragraphs or even whole pages ${ }^{58}$. Antoaneta Ralian even commented on the paradox that both as a translator and as a censor, she had to metaphorically "cover the nudes" and even eliminate authors that she would, ironically, translate herself after 1989 (such as Henry Miller), when she had move from excessive prudence to extreme transparency of language.

First the author had to be accepted.... This meant, mainly, the political attitude of the foreign author.... Was he an anticommunist? Or did he perhaps oppose Ceauşescu? Then there was no chance for his work to be accepted. ... Let us admit that the author was 'acceptable'. Then the topic was brought into question. In this respect, fluctuations have been recorded over the years. ... Especially nothing on religion! ... As far as love was concerned, it had to be platonic, as much as possible.... Finally, after this trial, the title came under discussion ${ }^{59}$.

This reference to Ceauşescu confirms that this was the period from the mid1960s on, coinciding with the liberalisation described above or rather with a well-controlled degree of freedom. The translations were diverse and of high standing, which made them a highly desired "commodity" that was instantly sold out, traded clandestinely and usually published in insufficient, albeit significant numbers of copies. Despite poor paper and graphic quality, the fact that the major world literature titles were available, with the inevitable changes or cuts (sometimes explicit in the text through ellipsis) made a huge cultural and emotional difference for more than one generation.

\section{Conclusions}

$\prod$ The issue of translations is, perhaps, one of the most interesting when censorship is considered, because what is translated and how it is performed reflects many aspects about the level of constraint during a dictatorship and the messages that an undemocratic system wants to convey. An example in this respect is Francoist Spain, in which film dubbing flourished (and is very popular until today) because, initially, it facilitated the elimination or change of certain undesired elements. Moreover, in Romania, in the Stalinist-style censorship system, control over the printed text (but also over visual representations, from official photographs and caricatures to films) reached Orwellian levels. The relaxation of censorship mentioned above brought a major change in the field of translations in the early 1960s. It was also apparent in the local literature with Neomodernism flourishing after the mid1960s, and cinema and television diversification. It was a short intermezzo, followed by the intensifying of Ceauşescu's cult of personality, which suffocated culture.

The memoirs discussed in this paper are valuable testimonies from inside the system, revealing how the mechanisms of both censorship and (at least partial) censorship elusion functioned. These are valuable testimonies, documenting the translation system from professionals that experienced the 
entire communist period with the political and censorship shifts, surviving them both physically and mentally. Understanding the changes in the intensity of censorship practices, these translators reflected on how, using different strategies, they could ensure that world literature masterpieces could reach the readers, escaping the purge or disfiguration of censorship (an actual "bibliocaust", as the Time magazine called it).

In this context, diaries and memoirs on Cold War translations reveal both the experience and the role of these professionals in escaping censorship (knowing its mechanisms, as Ralian did, for instance, since she had previously worked within the structures of the political apparatus). Life writing remains most prominent in these traumatic contexts, probably as it has to do with inner survival and with the preservation of mental health. It can also be connected with the justification of a sort of internal resistance and schizoid thinking in relation to the political invasion. But in the case of translations, it adds the component of book survival. They opened a window for the readers, facilitating access to good literature for millions of readers and contributing indirectly to their own resistance and survival within a world that was, for decades, suffocating.

This article has been supported by a STARUBB Advanced Fellowship grant (2020)

\section{REFERENCES}

Cassian, Nina, Memoria ca zestre, Vol.1, Bucureşti, Editura Institutului Cultural Român, 2003. Connelly,John, Captive University: the Sovietization of East German, Czech, and Polish Higher Education, 1945-1956, Chapel Hill, The University of North Carolina Press, 1999.

Cordoş, Sanda, Literatura între revoluție şi reacţiune, 2nd Edition, Cluj-Napoca, Biblioteca Apostrof, 2002 [1999].

- Lumi din cuvinte. Reprezentări şi identități în literatura românească postbelică, Bucureşti, Cartea Românească, 2012.

Cornea, Paul, Ce a fost-cum a fost. Paul Cornea de vorbă cu Daniel Cristea-Enache, Iaşi, Polirom, 2013.

Cozea, Liana, Confesiuni ale eului feminin, Piteşti, Paralela 45, 2005.

Dobrenko, Evgeny, Eric Naiman (eds.), The Landscape of Stalinism: The Art and Ideology of Soviet Space, Seattle \& London, University of Washington Press, 2003.

Dobrenko, Evgeny, The Making of the State Writer: Social and Aesthetic Origins of Soviet Literary Culture, Stanford, Stanford University Press, 2000.

Dragomir, Lucia, "L'implantation du réalisme socialiste en Roumanie", in Sociétés Ė représentations, no.1, 2003, p. 307-324.

Eliade, Mircea, Jurnalul portughez şi alte scrieri, vol. I. Bucureşti, Humanitas, 2006.

Fătu-Tutoveanu, Andrada, Sanda Cordoş, (eds.), "Communism - Negotiation of Boundaries", in Echinox/Echinox Journals, no. 19, Presses Universitaires de Valenciennes, 2010.

Fătu-Tutoveanu, Andrada, Rubén Jarazo Álvarez (eds.), Press, Propaganda and Politics: Cultural Periodicals in Francoist Spain and Communist Romania, Cambridge Scholars Publishing, 2013.

Fătu-Tutoveanu, Andrada, Building Socialism, Constructing People, Cambridge Scholars Publishing, 2014. - Personal Narratives of Romanian Women during the Cold War (1945-1989): Varieties of the Autobiographical Genre, Lewiston, Edwin Mellen Press, 2015.

- "Soviet cultural colonialism: culture and political domination in the late 1940s-early 1950s Romania", in Trames, no.1, 2012, p. 77-93. 
Fitzpatrick, Sheila, The Cultural Front: Power and Culture in Revolutionary Russia, Ithaca \& NY \& London, Cornell University Press, 1992.

Gabanyi, Anneli Ute, Literatura şi politica în România după 1945, Translated by Ioana Cristescu, Bucureşti, Editura Fundaţiei Culturale Române, 2001.

Gheorghiu, Mihai Dinu, Intelectualii în câmpul puterii. Morfologii şi traiectorii sociale, Iaşi, Polirom, 2007. Gheorghiu-Dej, Gheorghe, Cuvintare rostită la Conferinţa organizației de partid a orașului București, 15 februarie 1961, Bucureşti, Editura Politică, 1964.

Ghiţescu, Micaela, Intre uitare şi memorie, Bucureşti, Humanitas, 2012.

Hodgkin, Katharine, Radstone, Susannah (eds.), Contested pasts: The politics of memory, Routledge, 2003. Ionescu-Gură, Nicoleta, Stalinizarea României: Republica Populară Română. 1948-1950: Transformări instituţionale, Introduction by Dinu C. Giurescu, Bucureşti, Bic All, 2005.

Kolakowski, L., Main Currents of Marxism: Its Rise, Growth and Dissolution, Oxford/New York, Oxford University Press, 1978.

Mignolo, Walter D, “Colonial and postcolonial discourse: cultural critique or academic colonialism?”, in Latin American Research Review 28, no. 3, 1993, p. 120-134.

Nazare, Daniel, "Press, Libraries and Secret Funds in Romania (1945-1989): Case Study", in Andrada Fătu-Tutoveanu, Rubén Jarazo Álvarez (eds.), Press, Propaganda and Politics: Cultural Periodicals in Francoist Spain and Communist Romania, Cambridge Scholars Publishing, 2013, p. 213-226.

Ornea, Zigu, Anii treizeci: extrema dreaptă românească, Fundației Culturale Române, 1995.

Paraschivescu, Radu, Toamna decanei: convorbiri cu Antoaneta Ralian, Bucureşti, Humanitas, 2011.

Pintilescu [Fătu-Tutoveanu], Andrada, "Communist Female Writers: Emancipation, Identity Construction Policies and Representation in Post-War Romania. Case Study: Cella Serghi”, in Nieves Pascual Soler, Ján Gbúr (eds.), Gender in Literature/ Rod v Literatúre. Košice, Pavol Jozef Šafárik University, 2013, p. 219-256.

"Probleme actuale ale literaturii din R.P.R. în lumina lucrărilor lui A.A. Jdanov", Viaţa românească, no. 9, 1951, p. 182-216.

Popa, Ioana, "Le réalisme socialiste, un produit d'exportation politico-littéraire", in Sociétés Ė Représentations, no. 15, 2003, p. 261-292.

Popa, Mircea, "Schimbarea de paradigma Vest-Est sau ocupaţia sovietica în cultură”, in Caietele Echinox. Postcolonialism E Postcomunism, no. 1, 2001, p. 134-139. http://phantasma.ro

Ralian, Antoaneta, Amintirile unei nonagenare: calatoriile mele, scriitorii mei, Bucureşti, Humanitas, 2014. - Nu cred în sfârşitul lumii, Bucureşti, Humanitas, 2016.

Rolf, Malte, “A Hall of Mirrors: Sovietizing Culture under Stalinism”, in Slavic Review, no. 68 (3), 2009, p. 601-630.

Selejan, Ana, Literatura în totalitarism. 1949-1951, Bucureşti, Cartea Românească, 2007.

Tismaneanu, Vladimir, Cristian Vasile, Perfectul acrobat: Leonte Răutu, măștile răului, Bucureşti, Humanitas, 2008.

Vasile, Aurelia, Le cinéma roumain pendant la période communiste: représentations de l'bistoire nationale, Bucureşti, Editura Universităţii din Bucureşti, 2011.

Vasile, Cristian, Vladimir Tismăneanu, Literatura şi artele în România comunistă: 1948-1953, Humanitas, 2010.

Vasile, Cristian, «Ne trebuie oameni!» Elite intelectuale şi transformări istorice în România modernă și contemporană, Târgovişte, Cetatea de Scaun, 2017.

- Politicile culturale comuniste în timpul regimului Gheorghiu-Dej, Bucureşti, Humanitas, 2011.

Zavarache, Camelia, "Geometria unei relații complexe: elite, modele ale modernizării statale și regimuri politice în România secolului XX", in Cristian Vasile (ed.), "Ne trebuie oameni!" Elite intelectuale şi transformări istorice în România modernă şi contemporană, Târgoviş̧te, Cetatea de Scaun, 2017. 
Masterpieces in an Inferno. Censorship in Cold War Translation Experiences

\section{NoTES}

1. "La ședinţa de prelucrare a Hotărarilor Plenarei din august 1953 cu oamenii de creaţie, ţinută la Secţia de Literatură și Artă probabil in septembrie 1953, M. Novicov s-a exprimat in favoarea relaxării filtrului cenzorial: „Cred că trebuie revizuită și exigenţa, cateodată exagerată. Cred că este foarte pozitiv [sic!] faptul că Comitetul pentru Artă a lărgit chingile in artă; și in domeniul cinematografiei trebuie să slăbim chingile exigenţei. Noi am ajuns la cinema tografie că, practic [subl. n.], in mare măsură, scenariile se scriu acolo [la Comitetul pentru Cinematografie]. Cum [se] pune practic atragerea scriitorului, cand el nu are satisfacţia lucrării lui? Scriitorul trebuie ajutat să finiseze el scenariul. Din moment ce Comitetul de Cinematografie se substituie și face aceasta [rescrierea scenariului] in bucătăria sa, aceasta nu [il] poate atrage pe scriitor". (Cristian Vasile, Politicile culturale comuniste in timpul regimului Gheorghiu-Dej, București, Humanitas, 2011, p. 239).

2. Nina Cassian, Memoria ca zestre, Vol.1, București, Editura Institutului Cultural Român, 2003, p. 124. 3. Gheorghe Gheorghiu-Dej, Cuvîntare rostită la Conferinţa organizației de partid a orașului București, 15 februarie 1961, București, Editura Politică, 1964, p. 21.

4. Andrada Fătu-Tutoveanu, "Soviet cultural colonialism: culture and political domination in the late 1940s-early 1950s Romania”, in Trames, no.1, 2012, p. 77-93.

5. Andrada Fătu-Tutoveanu, Op. cit., p. 91.

6. John Connelly, Captive University: the Sovietization of East German, Czech, and Polish Higher Education, 1945-1956, Chapel Hill, The University of North Carolina Press, 1999, p. 107.

7. Walter D Mignolo, "Colonial and postcolonial discourse: cultural critique or academic colonialism?” in Latin American Research Review 28, no. 3, 1993, p. 125.

8. Ibidem, p. 88, 91.

9. Ioana Popa, "Le réalisme socialiste, un produit d'exportation politico-littéraire", in Sociétés E Représentations, no. 15,2003 , p. 262-263.

10. Camelia Zavarache, "Geometria unei relații complexe: elite, modele ale modernizării statale și regimuri politice în România secolului XX", in Cristian Vasile (ed.), "Ne trebuie oameni!." Elite intelectuale şi transformări istorice în România modernă şi contemporană, Târgovişte, Cetatea de Scaun, 2017, p. 229.

11.Vladimir Tismaneanu, Cristian Vasile, Perfectul acrobat: Leonte Răutu, măștile răului, Bucureşti, Humanitas, 2008, p. 270.

12. Andrada Fătu-Tutoveanu, Op. cit.; Andrada Fătu-Tutoveanu, Rubén Jarazo Álvarez (eds.), Press, Propaganda and Politics: Cultural Periodicals in Francoist Spain and Communist Romania, Cambridge Scholars Publishing, 2013

13. Paul Cornea, Ce a fost-cum a fost. Paul Cornea de vorbă cu Daniel Cristea-Enache, Iaşi, Polirom, 2013, p. 125.

14. Andrada Fătu-Tutoveanu, Building Socialism, constructing people, Cambridge Scholars Publishing, 2014, p.125.

15. Vladimir Tismaneanu, Cristian Vasile, Op. cit., p. 40.

16. Ibidem, p. 43-44.

17. Antoaneta Ralian, Nu cred în sfârşitul lumii, Bucureşti, Humanitas, 2016, p. 69-74.

18. A communist ideologist from a Russian speaking Jewish family from Bessarabia, today Republic of Moldova and considered a Soviet emissary in Romania.

19. Răutu qtd. in Vladimir Tismaneanu, Cristian Vasile, Op. cit., p. 37.

20. Lucia Dragomir, "L'implantation du réalisme socialiste en Roumanie", in Sociétés E̋ représentations, no. 1,2003 , p. 310.

21. Ibidem, p. 310.

22. Liana Cozea, Confesiuni ale eului feminin, Piteşti, Paralela 45, 2005, p. 13.

23. Micaela Ghiţescu, Intre uitare şi memorie, Bucureşti, Humanitas, 2012, p. 10; Antoaneta Ralian, Amintirile unei nonagenare: calatoriile mele, scriitorii mei, Bucureşti, Humanitas, 2014, p. 178.

24. Idem, Nu cred în sfârșitul lumii, București, Humanitas, 2016. 
25. Andrada Fătu-Tutoveanu, Op. cit., p. 11.

26. Micaela Ghiţescu, Op. cit., p. 63, 87.

27. Ibidem, p. 91.

28. Ibidem, p. 91.

29. Ibidem, p. 129.

30. Ibidem, p. 129-130.

31. Ibidem, p. 139.

32. Ibidem [Between Oblivion and Memory].

33. Ibidem, p. 9.

34. Ibidem, p. 10.

35. Ibidem, p. 140.

36. Katharine Hodgkin, Susannah Radstone (eds.), Contested pasts: The politics of memory, Routledge, 2003, p. 5 .

37. Ibidem, p. 9.

38. Ibidem, p. 131.

39. Ibidem, p. 136.

40. Ibidem, p. 39.

41. Mircea Popa, "Schimbarea de paradigma Vest-Est sau ocupaţia sovietica în cultură", in Caietele Echinox. Postcolonialism \& Postcomunism, no. 1, 2001, http://phantasma.ro (n.pag.).

42. Daniel Nazare, "Press, Libraries and Secret Funds in Romania (1945-1989): Case Study", in Andrada Fătu-Tutoveanu, Rubén Jarazo Álvarez (eds.), Press, Propaganda and Politics: Cultural Periodicals in Francoist Spain and Communist Romania, Cambridge Scholars Publishing, 2013, p. 215.

43. Micaela Ghiţescu, Op. cit., p. 146.

44. Paul Cornea, Op. cit., p. 128.

45. Mircea Eliade, Jurnalul portughez şi alte scrieri, vol. I. Bucureşti, Humanitas, 2006, p. 295.

46. Ibidem, p. 311.

47. Micaela Ghiţescu, Op. cit., p. 143.

48. Antoaneta Ralian, Op. cit., p. 71.

49. Ibidem, p. 72.

50. Ibidem, p. 72.

51. Ibidem, p. 72-73.

52. Aurelia Vasile, Le cinéma roumain pendant la période communiste: représentations de l'histoire nationale, Bucureşti, Editura Universităţii din Bucureşti, 2011, p. 114.

53. Editura de Stat pentru Literatură și Artă [The State Publishing House for Literature and Art], founded in 1948.

54. Aprox. translation The Literature Publishing House. The change, eliminating the reference to the state, may be read as a sign of liberalisation and at least of an illusion of independence and freedom in the publishing system.

55. Cristian Vasile, Politicile culturale comuniste în timpul regimului Gheorghiu-Dej, București, Humanitas, 2011, p. 152.

56. Micaela Ghiţescu, Op. cit., p. 139.

57. Ibidem, p. 140.

58. Ibidem, p. 141.

59. Ibidem, p. 141. 